\title{
Physical and Relational Aggressive Behavior in Preschool: School Teacher Rating, Teachers' Perception and İntervention Strategies
}

\author{
Esra Dereli (Corresponding author) \\ Department of Preschool Education, Eskişehir Osmangazi University \\ P.O. Box 26050, Eskişehir, Turkey
}

Tel: 90-222-239-3750 E-mail: derelie@ogu.edu.tr

Received: April 9, 2020 Accepted: May 30, 2020 Published: June 2, 2020

doi:10.5296/jei.v6i1.16947ＵRL: https://doi.org/10.5296/jei.v6i1.16947

\begin{abstract}
In this study was aimed to determine the preschool teachers' perception and intervention strategies of physical, relational aggressive behavior and investigate the whether preschool students' this aggressive behavior differ based on preschool teachers' intervention strategies. Sample group consisted of 42 pre-school teachers and 755 preschool students aged 4-5. Sequential explanatory design of explanatory design model, one of the mixed method designs, was used in the study. In the quantitative part of study relational screening model and the qualitive part of study semi-structured interview was used to assess teachers' perception and intervention. Personal Information Form, Pre-School Social Behavior Scale-Teacher Form, and Teacher Interview Forms were used to collect data. Analysis of data was used descriptive statistics, One Way Anova analysis. Results indicated that children's physical and relational aggressive behavior scores significantly differed preschool teachers' intervention strategies of aggressive behavior. According to the results, moderate level meaningful relationships between teachers' preschool teachers' intervention strategies of physical, relational aggressive behavior and students' physical and relational aggressive behavior. Teachers stated that they tried different ways to intervention strategies these problems. However, it was determined that pre-school teachers used the strategy of prohibition and punishment in physical aggression more than relational aggression.
\end{abstract}

Keywords: Physical aggression, Relational aggression, Intervention, Preschool education

\section{Introduction}

Preschool period is critical in the development of children. One of the development areas that 
children should be supported in this period is their social development. Children's social development includes the behaviors and attitudes that represent the understanding of social relationships and the development of appropriate psychosocial functioning skills, and the behaviors that children develop through their interaction with adults and peers. Social behavior is the ability of human beings to acquire knowledge, skills and attitudes to interact with another person and to turn this ability into action. The effect of family, teachers and peers on children's acquisition of social behavior is a widely accepted fact early childhood period is very important for children to acquire social behaviors. During this period, the child is rehearsing real life, experiencing and learning many behaviors by imitating adults (Ahmetoğlu, 2018; Blair et al., 2004; Gornik et al., 2018). Children learn new behaviors by observing their parents, teachers and other individuals, including peers, in this way they develop new skills and gain new knowledge. For children, the basis of learning social behavior is to find the appropriate model who demonstrates the relevant behavior. In this period, teachers have a significant impact on children's social behavior, as well as their parents. Children accept their teachers as role models, especially in the school environment, due to the strong socio-emotional relationships and the daily time spent with them. By observing the social behaviors of the teacher, the child will make social connections according to a model and will be developed socially in this way. In addition, the teacher will contribute to the child's successful development by organizing teamwork with other children in the classroom so that children can establish friendly relations with their peers, by creating opportunities to observe and learn about social behaviors and to make self-assessment.

Early childhood classroom is usually the first official peer group of children - and it has been suggested that young children's teachers tend to emphasize the development of social behaviors rather than academic skills (Lara-Cinisomo et al., 2009; Lee, 2006; Hollingsworth \& Winter, 2013). Accordingly, preschool teachers are thought to play a particularly critical role in facilitating children's social development. However, although preschool teachers reinforce children's social behaviors, negative social behaviors are also observed in the classroom (Del'Homme et al., 1994; Elliott \& Treuting, 1991). Children often tend to exhibit aggressive behavior when they have conflicts with their peers (Kamper-DeMarco \& Ostrov, 2018). Aggression is the behavior that is attempted or realized with the intention to harm another person physically or psychologically (Bartol, 1995). Therefore, aggression is defined as the behavior that harms or threatens others. Physical aggression refers to the intention of harming others using physical and verbal threats or harming others physically by using physical force, such as hitting and pushing (Crapanzano et al., 2010). Relational aggression is a form of non-physical aggression that directly and/or indirectly damages and hinders social relationships of other individuals (Archer \& Coyne, 2005; Crick \& Grotpeter, 2005; Crick et al., 2006). Relational aggression includes direct or indirect actions towards a child when complied against one's will, such as the threat of unfriending, social exclusion or silent treatment, as well as false rumors leading to refusal by classmates. Relational aggression is the actions such as not allowing a peer to play with them, making others dislike the peer, unfriending someone that they pissed off, ignoring a peer socially, which damage peer relationships, externalize a peer, involving threats. Teachers and parents perceive physical aggression in children as more offending and having more negative consequences than 
relational aggression. Physical aggression is perceived as more offending and frightening with more negative consequences than relational aggression. Relational aggression, which is also known as indirect aggression, is a passive-aggressive, manipulative way of harming others. This aggression can have devastating effects for both the aggressor and the targeted child. Physical aggression causes physical damage in children, whereas relational aggression causes psychological damage in them. Relational aggression is a form of deliberate and hidden bullying aiming to harm others through social exclusion, humiliation in front of the community, and personal rejection. Regarding early childhood period, aggressive behavior towards peers begins to be seen around the age of three. With the development of verbal and social cognitive skills around the age of 4-5, children start to use relational aggression. Brendgen et al. (2006) discovered that children's relational aggression may cause as much harm as physical aggression. However, children often think that relational aggression behaviors such as nicknaming their peers and spreading rumors do not carry the risk of being punished as much as physical aggressive behavior such as hitting someone As a result, relational aggression behaviors become the main strategy of children and they become more proficient in using these behaviors as they get older. Lim and Hoot (2015) suggest that relational aggression began in early childhood, continued during primary school years, became more common in these years and children used a wider variety of tactics. Consequently, the aggression experiences that children face in early childhood harm them and negatively affect their social development. Peer interactions of children in early childhood are very important. Because; first, children between the ages of 3 and 5 can exhibit simple forms of physical and relational aggression. Second, if aggression damages the ability of preschool children to establish good relationships with others, learning to build positive, supportive relationships with their peers, which is one of the important developmental tasks of childhood, may be delayed. Third, having a friend serves as a protective factor against the development or deterioration of various forms of maladaptation. Fourth, friendship exists in the preschool period and it is meaningful for children.

Preventing physical and relational aggression behaviors that children exhibit in early childhood will prevent the negative experiences of both the aggressive child who exhibits aggressive behavior and the child who is the target of the aggressive behavior. The strategies used by the teacher for preventing and interfering the physical and relational aggression observed in early childhood during the first peer interaction are thought to be important. The review of the relevant literature revealed that researches were conducted to determine the social behaviors, physical and relational aggression of the children, but it was found that there was no research investigating how teachers' intervention methods predict children's social behavior and aggression types. In this study, it was aimed to determine the preschool teachers' perception and intervention strategies of physical, relational aggressive behavior and investigate the whether preschool students' physical, relational aggressive behavior differ based on preschool teachers' intervention strategies.

In this research, it is aimed to answer the following questions.

Is there a significant relationship between children's social behavior, relational aggression and teachers' intervention strategies for relational aggression and physical aggression? 


\section{Macrothink

Do the child's relational aggression levels differ according to the intervention strategies of the teachers regarding relational aggression and physical aggression?

Do the child's social behavior levels differ according to the intervention strategies of the teachers regarding relational aggression and physical aggression?

What are the opinions of teachers about the strategies they use in interventions regarding children's physical and relational aggression?

\section{Method}

In this study was used Sequential Explanatory Design one of Mixed-Methods. This model involves the use of qualitative data to explain and reinterpret quantitative data. Content analysis was applied to qualitative data and they were used to explain quantitative research findings. In the quantitative part of the research, relational screening model, one of the screening models, was used (Karasar, 2018). In the qualitive part of study semistructured interview was used to assess teachers' perception and intervention of physical and relational aggressive behaviours in preschool children.

\subsection{Sample}

The target population of the quantitative part of the study is comprised of the children aged 4-5, attending nursery class in independent kindergartens and kindergartens within primary education, in the 2019-2020 academic year, in Turkey. The sample of the quantitative part of the study consists of 755 randomly selected children from fifteen different pre-school institutions selected from the study population (Büyüköztürk et al., 2008; Fraenkel \& Wallen, 2006). The target population of the qualitative part of the study is comprised of preschool education teachers, working in nursery class of kindergartens in the 2019-2020 academic year in Turkey. Information about the sample of the research is presented in Table 1. 
Table 1. The demographic characteristics of the sample group

\begin{tabular}{|c|c|c|c|}
\hline $\begin{array}{ll}\text { Children's } & \text { Demographic } \\
\text { Characteristics } & \end{array}$ & Variable & $\mathrm{N}$ & $\%$ \\
\hline Gender & $\begin{array}{l}\text { Female } \\
\text { Male }\end{array}$ & $\begin{array}{l}364 \\
391\end{array}$ & $\begin{array}{l}48.2 \\
51.8\end{array}$ \\
\hline Age & $\begin{array}{l}4 \\
5-5.5\end{array}$ & $\begin{array}{l}347 \\
408\end{array}$ & $\begin{array}{l}46.0 \\
54.0\end{array}$ \\
\hline Income Status & $\begin{array}{l}2001-3000 \mathrm{TL} \\
3001-4000 \mathrm{TL} \\
4001+\mathrm{TL}\end{array}$ & $\begin{array}{l}313 \\
223 \\
219\end{array}$ & $\begin{array}{l}41.5 \\
29.5 \\
29.0\end{array}$ \\
\hline Teacher Working Year & $\begin{array}{l}\text { 0-5 Year } \\
6-10 \text { Year } \\
11-15 \text { Year } \\
16-20 \text { Year }\end{array}$ & $\begin{array}{l}4 \\
18 \\
14 \\
6\end{array}$ & $\begin{array}{l}9.52 \\
42.86 \\
33.33 \\
14.29\end{array}$ \\
\hline
\end{tabular}

\subsection{Instruments}

Demographic Information Form: This form was used to determine demographic characteristics (age, gender, family income level) and teacher features (working year) of sample.

Teachers' Interview Form: Two questions were posed to the teachers in the semi-structured interview form; "Do children in your class have physical and relational aggression behaviors? If so, what are the interventions you apply against children's physical and relational aggression behaviors?"

Preschool Social Behavior Scale-Teacher Form: This form was developed by Crick, Casas and Mosher (1997) to determine the prosocial behavior and aggression types of 3-6 years old children based on the perception and assessment of the teachers. The Cronbach Alpha coefficients were .96 for relational aggression, .94 for open/physical aggression, .88 for positive social behavior, and .87 for depressive affect (Crick et al., 1997). This form was adapted to Turkish language by Şen and Ar1 (2011). In confirmatory factor analysis, the scale Chi-square value was calculated as $637.76(\mathrm{p}<.01)$, and its ratio to the degree of freedom was $637.76 / 241=2.6$. In confirmatory factor analysis, it was determined that RMSEA was .08, GFI value was .81, and AGFI value was .76. Cronbach alpha internal consistency coefficients were $.95 ; .89 ; .90$ and .51 , respectively. Test-retest reliability coefficients were $.85 ; .81 ; .73$ and .56 , respectively (Şen \& Ar1, 2011).

\subsection{Procedure}

In order to conduct the research, the suitability of the study for children aged 4-5 years has been approved by the ethics committee of the university and Eskişehir Provincial Directorate 
of National Education. In the research, Social Competence and Behavior Evaluation Form was filled by the teachers of the children. Afterwards, semi-structured interviews were conducted with the teachers of the children participating in the research. The individual interview with the teacher lasted approximately 40 minutes.

\subsection{Data Analysis}

The normality of data checked using Kolmogorov-Smirnov Z-test and verified that the data normally distributed ( $Z$ varing from 1.63 to 1.84 ). In addition, homogeneity of data were tested with levene test and identified that data were distributed homogeneously. Thus, guantitative part of research, the data were analysed with Pearson Product-Moment Correlation and One Way Anova. Teachers' responses for the openended questions in qualitative interview form were analysed with content analysis. After obtaining intervention strategies from the teachers, the coding of intervention strategies related to two types of aggression was performed based on the codes used by Mize et al. (1995), Colwell et al. (2002), Juliano et al. (2006). Accordingly, the intervention strategies against the aggression behaviors obtained from the teachers were gathered under four themes; namely discussion, encouragement, power assertion and rule violation. Using Colwell et al. (2002) definitions, these four themes were rated as 1 (low), 2 (medium) and 3 (high) according to the teachers' usage level. In addition, coding by three independent researchers were compared and different codes were revised according to the proposals of another field expert and a consensus was reached. The reliability of the coding process has been checked using the inter-rater reliability formula proposed by Miles and Huberman (1994). The reliability of the independent codings have been found to be $87.4 \%$ and $92.6 \%$ respectively for relational aggression and physical aggression of children. This result can be considered as the proof for reliability, as it is over 70\% (Miles \& Huberman, 1994).

\section{Results}

Findings obtained from sample group children and teacher data are displayed in tables.

Table 2. The relationship between social behavior, relational aggression and teachers' intervention strategies related to relational aggression

\begin{tabular}{|l|l|l|l|l|}
\hline & Discussion & Encouragement & Power assertion & Rule violation \\
\hline Social behavior & $.455^{* *}$ & $.389^{* *}$ & $-.346^{* *}$ & $-.426^{* *}$ \\
\hline Relational aggression & $-.826^{* *}$ & $-.746^{* *}$ & $.601 * *$ & $.708^{* *}$ \\
\hline
\end{tabular}

Note. ${ }^{* *} \mathrm{P}<.01$.

Positive correlation between children's social behavior and teachers' discussion and encouragement intervention strategies. Negative correlation between children's social behavior and teachers' power assertion and rule violation intervention strategies teachers' related to relational aggression. There was negative correlation between children's relational 
aggression and teachers' discussion and encouragement intervention strategies, teachers' intervention strategies positive correlation between children's relational aggression and teachers' power assertion and rule violation intervention strategies related to relational aggression.

Table 3. The relationship between social behavior, physical aggression and teachers' intervention strategies related to physical aggression

\begin{tabular}{|l|l|l|l|l|}
\hline & Discussion & Encouragement & Power assertion & Rule violation \\
\hline Social behavior & $.347^{* *}$ & $.309^{* *}$ & $-.341^{* *}$ & $-365^{* *}$ \\
\hline Physical aggression & $-607^{* *}$ & $-.540^{* *}$ & $.564^{* *}$ & $.669^{* *}$ \\
\hline
\end{tabular}

Note. $* * \mathrm{P}<.01$.

Positive correlation between children's social behavior and teachers' discussion and encouragement intervention strategies negative correlation between children's social behavior and teachers' power assertion and rule violation intervention strategies related to physical aggression. There was negative correlation between children's physical aggression and teachers' discussion and encouragement intervention strategies, positive correlation between children's physical aggression and teachers' power assertion and rule violation intervention strategies related to physical aggression.

Table 4. Descriptive statistics for child's social behavior, aggression types and pre-school teachers' intervention strategies scores

\begin{tabular}{|l|l|l|}
\hline Variable & Mean & Std. Deviation \\
\hline Physical aggression & 15.866 & 9.351 \\
\hline Social behavior & 24.797 & 7.981 \\
\hline Relational aggression & 16.131 & 7.749 \\
\hline Relational aggression & 2.015 & .822 \\
\hline Encouragement & 2.099 & .830 \\
\hline Discussion & 2.141 & .838 \\
\hline Power assertion & 2.231 & .832 \\
\hline Rule violation & \multicolumn{2}{|l|}{} \\
\hline Physical aggression & 1.633 & .6108 \\
\hline Encouragement & 1.847 & .7924 \\
\hline Discussion & 2.260 & .7790 \\
\hline Power assertion & 2.170 & .7699 \\
\hline Rule violation & &
\end{tabular}


Table 5. One Way Anova results for children's relational aggression based on teachers' intervention strategies related to relational aggression

\begin{tabular}{|c|c|c|c|c|c|}
\hline Relational Aggression & Variance Source & Sum of Squares & df & Mean Square & $\mathrm{F}$ \\
\hline Discussion & $\begin{array}{l}\text { Between Groups } \\
\text { Within Groups } \\
\text { Total }\end{array}$ & $\begin{array}{l}31550,153 \\
13731,865 \\
45282,019\end{array}$ & $\begin{array}{l}2 \\
752 \\
754\end{array}$ & $\begin{array}{l}15775,077 \\
18,260\end{array}$ & $863,893 * *$ \\
\hline Encouragement & $\begin{array}{l}\text { Between Groups } \\
\text { Within Groups } \\
\text { Total }\end{array}$ & $\begin{array}{l}25381,636 \\
19900,383 \\
45282,019\end{array}$ & $\begin{array}{l}2 \\
752 \\
754\end{array}$ & $\begin{array}{l}12690,818 \\
26,463\end{array}$ & $479,563 * *$ \\
\hline Power Assertion & $\begin{array}{l}\text { Between Groups } \\
\text { Within Groups } \\
\text { Total }\end{array}$ & $\begin{array}{l}16413,621 \\
28868,397 \\
45282,019\end{array}$ & $\begin{array}{l}2 \\
752 \\
754\end{array}$ & $\begin{array}{l}8206,811 \\
38,389\end{array}$ & $213,781 * *$ \\
\hline Rule violation & $\begin{array}{l}\text { Between Groups } \\
\text { Within Groups } \\
\text { Total }\end{array}$ & $\begin{array}{l}24060,361 \\
21221,657 \\
45282,019\end{array}$ & $\begin{array}{l}2 \\
752 \\
754\end{array}$ & $\begin{array}{l}12030,181 \\
28,220\end{array}$ & $426,295 * *$ \\
\hline
\end{tabular}

Note. $* * \mathrm{P}<.01$.

Table 5 indicates the significant differences between the children's relational aggression and teachers' discussion intervention strategies scores $(\mathrm{F}=863,893 \mathrm{p}<.01)$ and encouragement intervention strategies scores $(\mathrm{F}=479,563, \mathrm{p}<.01)$ related to relational aggression. There is difference between the children's relational aggression and teachers' power assertion intervention strategies scores $(\mathrm{F}=213,781, \mathrm{p}<.01)$ and rule violation intervention strategies scores $(F=426,295, p<.01)$ related to relational aggression. According to the results of LSD test, the higher discussion strategy used teachers-level related to relational aggression the decreases scores children's relational aggression score. Teachers who use the discussion strategy at the highest level related to relational aggression of children's relational aggression score was less than that of teachers who use he discussion strategy at medium; and minimum level. Also teachers who use the discussion strategy at medium level of children's relational aggression score was less than that of teachers who use the discussion strategy at minimum level. The higher encouragement strategy used teachers-level the decreases scores children's relational aggression score. Teachers who use the encouragement strategy at the highest level of children's relational aggression score was less than that of teachers who use the encouragement strategy at medium; and minimum level. Also teachers who use the encouragement strategy at medium level of children's relational aggression score was less than that of teachers who use the encouragement strategy at minimum level.

The higher power assertion strategy used teachers-level the increases scores children's relational aggression score. Teachers who use the power assertion strategy at the highest level of children's relational aggression score was higher than that of teachers who use the power assertion strategy at medium and minimum level Also teachers who use the power assertion 
strategy at medium level of children's relational aggression score was less than that of teachers who use the power assertion strategy at minimum level. The higher rule violation strategy used teachers-level the increases scores children's relational aggression score. Teachers who use the rule violation strategy at the highest level of children's relational aggression score was higher than that of teachers who use the rule violation strategy at medium and minimum level. Also teachers who use the rule violation strategy at medium level of children's relational aggression score was less than that of teachers who use the rule violation strategy at minimum level.

Table 6. One Way Anova results for children's physical aggression based on teachers'intervention strategies related to physical aggression

\begin{tabular}{|l|l|l|l|l|l|}
\hline Relational Aggression & Variance Source & Sum of Squares & df & Mean Square & F \\
\hline \multirow{4}{*}{ Discussion } & Between Groups & 25858,204 & 2 & 12929,102 & \multirow{2}{*}{$242,550^{* *}$} \\
& Within Groups & 40085,284 & 752 & 53,305 & \\
& Total & 65943,489 & 754 & & \\
\hline \multirow{5}{*}{ Encouragement } & Between Groups & 20345,611 & 2 & 10172,805 & $167,770^{* *}$ \\
& Within Groups & 44212,752 & 752 & 60,635 & \\
& Total & 65943,489 & 754 & & \\
\hline \multirow{3}{*}{ Rule violation } & Between Groups & 21730,737 & 2 & 10865,369 & $184,805^{* *}$ \\
& Within Groups & 44212,752 & 752 & 58,794 & \\
\hline & Total & 65943,489 & 754 & & \multirow{2}{*}{$193,172 * *$} \\
& Between Groups & 22380,613 & 2 & 11190,307 & \\
\hline
\end{tabular}

Note. $* * \mathrm{P}<.01$.

Table 6 indicates the significant differences between the children's physical aggression and teachers' discussion intervention strategies scores $(F=242,550 \mathrm{p}<.01)$ and encouragement intervention strategies scores $(\mathrm{F}=167,770, \mathrm{p}<.01)$ related to physical aggression . There is difference between the children's physical aggression and teachers' power assertion intervention strategies scores $(\mathrm{F}=184,805, \mathrm{p}<.01)$ and rule violation intervention strategies scores $(\mathrm{F}=193,172, \mathrm{p}<.01)$ related to physical aggression.

According to the results of LSD test, the higher discussion strategy used teachers-level the decreases scores children's physical aggression score. According to the results of LSD test, teachers who use the discussion strategy at the highest level of children's physical aggression score was less than that of teachers who use the discussion strategy at medium $(X=12,85)$; and minimum level. Also teachers who use the discussion strategy at medium level of children's physical aggression score was less than that of teachers who use the discussion 
strategy at minimum level. The higher encouragement strategy used teachers-level the decreases scores children's physical aggression score. Teachers who use the encouragement strategy at the highest level of children's physical aggression score was less than that of teachers who use the encouragement strategy at medium and minimum level. The higher power assertion strategy used teachers-level the increases scores children's physical aggression score.

Teachers who use the power assertion strategy at the highest level of children's physical aggression score was higher than that of teachers who use the power assertion strategy at medium and minimum level. Also teachers who use the power assertion strategy at medium level of children's physical aggression score was less than that of teachers who use the power assertion strategy at minimum level.

The higher rule violation strategy used teachers-level the increases scores children's physical aggression score. According to the results of LSD test, teachers who use the rule violation strategy at the highest level of children's physical aggression score; and minimum level. Also teachers who use the rule violation strategy at medium level of children's physical aggression score was less than that of teachers who use the rule violation strategy at minimum level.

Table 7. One Way Anova results for children's social behavior based on teachers' intervention strategies related to relational aggression

\begin{tabular}{|l|l|l|l|l|l|}
\hline Relational Aggression & Variance Source & Sum of Squares & df & Mean Square & F \\
\hline \multirow{4}{*}{ Discussion } & Between Groups & 10143,049 & 2 & 5071,524 & \multirow{2}{*}{$100,668^{* *}$} \\
& Within Groups & 37884,946 & 752 & 50,379 & \\
& Total & 48027,995 & 754 & & \\
\hline \multirow{5}{*}{ Encouragement } & Between Groups & 7272,127 & 2 & 3636,063 & \multirow{2}{*}{$67,090^{* *}$} \\
& Within Groups & 40755,868 & 752 & 54,197 & \\
& Total & 48027,995 & 754 & & \\
\hline \multirow{3}{*}{ Rule violation } & Between Groups & 5757,381 & 2 & 2878,691 & $51,212^{* *}$ \\
& Within Groups & 42270,613 & 752 & 56,211 & \\
& Total & 48027,995 & 754 & & \multirow{2}{*}{ Assertion } \\
& Between Groups & 8953,832 & 2 & $46,160^{* *}$ \\
\hline
\end{tabular}

Note. ${ }^{*} * \mathrm{P}<.01$.

Table 7 indicates the significant differences between the children's social behavior and teachers' discussion intervention strategies scores $(F=100,668 \mathrm{p}<.01)$ and encouragement intervention strategies scores $(F=67,090, p<.01)$ related to relational aggression. There is difference between the children's physical aggression and teachers' power assertion 


\section{Ml Macrothink}

intervention strategies scores $(\mathrm{F}=51,212, \mathrm{p}<.01)$ and encouragement intervention strategies scores $(F=67,090, p<.01)$ related to relational aggression.

According to the results of LSD test, the higher discussion strategy used teachers-level related to relational aggression the increases scores children's social behavior score. Teachers who use the discussion strategy at the highest level of children's social behavior score was higher than that of teachers who use the discussion strategy at medium and minimum level. Also teachers who use the discussion strategy at medium level of children's social behavior score was higher than that of teachers who use the discussion strategy at minimum level.

The higher encouragement strategy used teachers-level related to relational aggression the increases scores children's social behavior score. Teachers who use the encouragement strategy at the highest level of children's social behavior score was higher than that of teachers who use the encouragement strategy at medium; and minimum level. Also teachers who use the discussion strategy at medium level of children's social behavior score was higher than that of teachers who use the discussion strategy at minimum level.

The higher power assertion strategy used teachers-level related to relational aggression the decreases scores children's social behavior score. Teachers who use the power assertion strategy at the highest level of children's social behavior score was less than that of teachers who use the power assertion strategy at medium and minimum level. Also teachers who use the power assertion strategy at medium level of children's social behavior score was higher than that of teachers who use the power assertion strategy at minimum level.

According to the results of LSD test, the higher rule violation strategy used teachers-level related to relational aggression the decreases scores children's social behavior score. Teachers who use the rule violation strategy at the highest level of children's social behavior score was less than that of teachers who use the rule violation strategy at medium and minimum level. Also teachers who use the rule violation strategy at medium level of children's social behavior score was less than that of teachers who use the rule violation strategy at minimum level. 
Table 8. One Way Anova results for children's social behavior based on teachers' intervention strategies related to physical aggression

\begin{tabular}{|l|l|l|l|l|l|}
\hline Relational Aggression & Variance Source & Sum of Squares & df & Mean Square & F \\
\hline \multirow{4}{*}{ Discussion } & Between Groups & 5775,664 & 2 & 2887,832 & \multirow{2}{*}{$51,397 * *$} \\
& Within Groups & 42252,330 & 752 & 56,187 & \\
& Total & 48027,995 & 754 & & \\
\hline \multirow{5}{*}{ Encouragement } & Between Groups & 4944,334 & 2 & 2472,167 & \multirow{2}{*}{$43,150^{* *}$} \\
& Within Groups & 43083,661 & 752 & 57,292 & \\
& Total & 48027,995 & 754 & & \\
\hline \multirow{5}{*}{ Rule violation } & Between Groups & 5596,466 & 2 & 2798,233 & $49,592^{* *}$ \\
& Within Groups & 42431,529 & 752 & 56,425 & \\
& Total & 48027,995 & 754 & & \\
& Between Groups & 6389,521 & 2 & 3194,761 & $57,698^{* *}$ \\
& Within Groups & 41638,473 & 752 & 55,370 & \\
\hline
\end{tabular}

Note. $* * \mathrm{P}<.01$.

Table 8 indicates the significant differences between the children's social behavior and teachers' discussion intervention strategies scores $(F=51,397 \mathrm{p}<.01)$ and encouragement intervention strategies scores $(\mathrm{F}=43,150, \mathrm{p}<.01)$. There is difference between the children's physical aggression and teachers' power assertion intervention strategies scores $(\mathrm{F}=49,592$, $\mathrm{p}<.01)$ and teachers' rule violation intervention strategies scores $(\mathrm{F}=57,698, \mathrm{p}<.01)$.

According to the results of LSD test, the higher discussion strategy used teachers-level related to physical aggression aggression the increases scores children's social behavior score. Teachers who use the discussion strategy at the highest level of children's social behavior score was higher than that of teachers who use the discussion strategy at medium; and minimum level. Also teachers who use the discussion strategy at medium level of children's social behavior score was higher than that of teachers who use the discussion strategy at minimum level.

The higher encouragement strategy used teachers-level related to physical aggression the increases scores children's social behavior score. Teachers who use the encouragement strategy at the highest level of children's social behavior score was higher than that of teachers who use the encouragement strategy at medium and minimum level. Also teachers who use the discussion strategy at medium level of children's social behavior score was higher than that of teachers who use the discussion strategy at minimum level.

The higher power assertion strategy used teachers-level related to physical aggression the decreases scores children's social behavior score. Teachers who use the power assertion strategy at the highest level of children's social behavior score was less than that of teachers 
who use the power assertion strategy at medium and minimum level. Also teachers who use the power assertion strategy at medium level of children's social behavior score was higher than that of teachers who use the power assertion strategy at minimum level.

According to the results of LSD test, the higher rule violation strategy used teachers-level related to relational aggression the decreases scores children's social behavior score. Teachers who use the rule violation strategy at the highest level of children's social behavior score was less than that of teachers who use the rule violation strategy at medium; and minimum level. Also teachers who use the rule violation strategy at medium level of children's social behavior score was less than that of teachers who use the rule violation strategy at minimum level.

In addition to the quantitative results mentioned above, semi-structured interviews were conducted with the teachers' of children in the determine teachers' on strategies use to intervention and these findings and the analysis results for these interviews are presented below:

Table 9. The views of teachers' on strategies use to intervention related to children's relational aggression

\begin{tabular}{|c|c|c|c|}
\hline Theme & Sub-theme & Sample expressions & $\mathrm{f} / \%$ \\
\hline \multirow[t]{3}{*}{ Discussion } & Appeal to feelings & $\begin{array}{l}\text { - As a teacher, I organize role playing activities for children to } \\
\text { understand their feelings and develop empathy skills. } \\
\text { - I talk to child and help him understand how the other child can } \\
\text { feel. } \\
\text {-I will calm the child down and talk to him/her for empathy. } \\
\text {-I talk about how the heroes feel about their experiences in story } \\
\text { events. } \\
\text { - I say the behavior is wrong, and I'll talk about how you can } \\
\text { feel when it's done to you. } \\
\text {-Suddenly, the behavior does not change, but when I } \\
\text { communicate with children, when I speak, and when I } \\
\text { supported to empathize with them, I can see change }\end{array}$ & $8-19 \%$ \\
\hline & Explanation & $\begin{array}{l}\text { - I'm telling children about classroom rule and why there are } \\
\text { rules in the classroom. } \\
\text { - I explain why they should not do aggressive behavior. } \\
\text { - Even though we're right, I'm telling to children it's not right } \\
\text { to force people to do something. } \\
\text { - I explain that each individual can have different characteristics } \\
\text { by organizing activities related to individual differences. }\end{array}$ & $6-14 \%$ \\
\hline & Problem Solving & $\begin{array}{l}\text { - I will help the child to find solutions to the problems. } \\
\text { - I give children possible situations and talking face to face } \\
\text { about how they can solve these problems. }\end{array}$ & $7-17 \%$ \\
\hline
\end{tabular}




\begin{tabular}{|c|c|c|c|}
\hline & & $\begin{array}{l}\text {-I'm able to try out how they can solve problems experienced in } \\
\text { the classroom with the drama method. } \\
\text { - In story activities, I give opportunities children to find out how } \\
\text { they can solve problems in the classroom. } \\
\text { - I observe the situations in which the behavior occurs and try to } \\
\text { solve the problem with children. }\end{array}$ & \\
\hline & Information Seeking & $\begin{array}{l}\text { - I'il ask the kid why he/she did this. } \\
\text { - I asked what would be the consequences of behavior with } \\
\text { children. } \\
\text { - I talk to parents about what can happen is the cause of } \\
\text { behavior. } \\
\text { - I'll take the children's ideas and I create a discussion } \\
\text { environment. }\end{array}$ & $4-\% 10$ \\
\hline & General & $\begin{array}{l}\text { - I say it is not the correct behavior of aggression. } \\
\text { - I'm telling children that they can't eliminate your problems by } \\
\text { threatening your friends. } \\
\text { I tell children that aggressive behavior is not a pleasant thing. } \\
\text { - I talk to kids, I make sure to notice the error, giving immediate } \\
\text { feedback. } \\
\text { - I talked to the child and I'm signs of aggressive behavior that } \\
\text { is harmful. }\end{array}$ & $5-12 \%$ \\
\hline \multirow[t]{3}{*}{ Encouragement } & Facilitating play & $\begin{array}{l}\text { - I plan group activities to ensure the participation of each child. } \\
\text { - I help children understand each other and establish positive } \\
\text { relationships with drama method. }\end{array}$ & $10-24 \%$ \\
\hline & $\begin{array}{l}\text { Direct Involvement } \\
\text { in Children's Play }\end{array}$ & $\begin{array}{l}\text { - I become a role model for children to participate in their play } \\
\text { and show their appropriate behaviors and reinforce their } \\
\text { appropriate behavior in the play. } \\
\text { - I'm involved in kids' play and we create a new play. } \\
\text { - I'm trying to encourage the kids to play together. } \\
\text { - I become a model for children in social behavior and I } \\
\text { encourage them to exhibit these behaviors. }\end{array}$ & $11-26 \%$ \\
\hline & $\begin{array}{l}\text { Engaging in } \\
\text { Positive Play } \\
\text { with Peers }\end{array}$ & $\begin{array}{l}\text { - I'm talking about the importance of children to play together } \\
\text { and respect each other. } \\
\text { - When children exhibit positive behavior, I use sentences as } \\
\text { verbal praise behavior. } \\
\text { - I talk about the importance of playing play with their peers } \\
\text { and positive communication. } \\
\text { - I say that rewarded the child for his/her positive behavior. }\end{array}$ & $7-17 \%$ \\
\hline Power Assertion & Punishment & $\begin{array}{l}\text { - I give the child time out and I want him to think about his } \\
\text { aggressive behavior. } \\
\text { - As a result of his/her aggressive behavior, I give feedback and } \\
\text { deprive him/her of favorite }\end{array}$ & $12-29 \%$ \\
\hline
\end{tabular}




\begin{tabular}{|c|c|c|c|}
\hline & & $\begin{array}{l}\text {-I give feedback on the results of aggressive behavior, would } \\
\text { deprive his/her favorite activity. } \\
\text {-I take the child to the resting corner, waiting for her/his to calm } \\
\text { down and distancing her/his from group activities. } \\
\text { - I'm distancing from group activities, leaving it alone and } \\
\text { waiting to calm down. } \\
\text { - I deprives children of a certain time from favorite toys when is } \\
\text { showing aggressive behavior. }\end{array}$ & \\
\hline & Prohibitions & $\begin{array}{l}\text { - I remind children of the rules. } \\
\text { - I forbid children to behave in an aggressive manner to each } \\
\text { other. } \\
\text { - I help the children to adopt rules in the classroom. } \\
\text { - I repeat the class rules with visuals every day at the start of the } \\
\text { day. } \\
\text { - I'm hanging the rules that we have to obey the class. } \\
\text { - I'm building a behavior board in the classroom, and I'm } \\
\text { telling you that when you're in a negative attitude, you don't } \\
\text { win the stick. }\end{array}$ & $7-17 \%$ \\
\hline & $\begin{array}{l}\text { Removal/ } \\
\text { Distraction }\end{array}$ & $\begin{array}{l}\text { - I'm distancing children from each other and I'm not putting } \\
\text { them together for a while. } \\
\text {-Children when conflict living, I'm away from the environment } \\
\text { they live in conflict. } \\
\text { - I help children find a different activity. } \\
\text { - I set up different playgrounds for both children who live in } \\
\text { conflict. }\end{array}$ & $5-12 \%$ \\
\hline & Reprimand & - I would tell the child that her/his behavior was unacceptable. & $2-5 \%$ \\
\hline & Reparations & $\begin{array}{l}\text { - I'll tell the child who has aggressive behavior to give the toy } \\
\text { to her/his friend. } \\
\text { - I create educational environments that will reduce the negative } \\
\text { behaviors of children. I provide enough play material for every } \\
\text { child. }\end{array}$ & $3-7 \%$ \\
\hline \multirow[t]{3}{*}{ Rule violation } & Reassurance & - I will calm down and comfort the child exposed to aggression. & $4-\% 10$ \\
\hline & $\begin{array}{l}\text { Target Victim rather } \\
\text { than Aggressor }\end{array}$ & $\begin{array}{l}\text { - I tell the child who is exposed to aggression to take another } \\
\text { activity instead of this activity. } \\
\text { - I'm telling other children to take care of their friends and want } \\
\text { other children to play with this child. } \\
\text { - I'm always trying to be active with the quiet child. }\end{array}$ & $14-33 \%$ \\
\hline & Distract from Problem & $\begin{array}{l}\text { - I take away the child who is having problems with her/his } \\
\text { friend from the environment and directs them to different } \\
\text { activities. } \\
\text { - I offer active participation to the silent child in group } \\
\text { activities. }\end{array}$ & $12-29 \%$ \\
\hline
\end{tabular}




\begin{tabular}{|l|l|l|l|}
\hline & & $\begin{array}{l}\text { - I ignore the aggressive behavior of the child, reward their } \\
\text { positive behavior. } \\
\text { - I plan group events where the excluded child can also } \\
\text { participate. }\end{array}$ & $3-7 \%$ \\
\hline $\begin{array}{l}\text { Teacher join Promote } \\
\text { ongoing Interaction }\end{array}$ & $\begin{array}{l}\text { - I take the child who is exposed to aggression and go to the } \\
\text { other children and talk to them to play together. } \\
\text { - I'd be guided (pioneered) to play with friends. }\end{array}$ & \\
\hline
\end{tabular}

Review of table 9 demonstrated that teachers generally use the methods of discussion and encouragement as solution-based intervention strategies to prevent relational aggression. Teachers stated that they generally use the methods of power assertion and rule violation non solution-based intervention strategies to prevent relational aggression.

Table 10. The views of teachers' on strategies use to intervention related to children's physical aggression

\begin{tabular}{|c|c|c|c|}
\hline Theme & Sub-theme & Sample expressions & $\mathrm{f} / \%$ \\
\hline \multirow{4}{*}{ Discussion } & Appeal to feelings & $\begin{array}{l}\text { - I tell the child that when hurt her/his friend, friend would be } \\
\text { upset. } \\
\text { - I say the behavior is wrong, and I'll talk about how you can feel } \\
\text { when it's done to you. } \\
\text { - I speak to the child and help her/him to empathize with her/his } \\
\text { friend. } \\
\text { - Suddenly, the behavior does not change, but when I communicate } \\
\text { with children, when I speak, and when I supported to empathize } \\
\text { with them, I can see change. }\end{array}$ & $6-14 \%$ \\
\hline & Explanation & $\begin{array}{l}\text { - I talk to the child face to face and tell her/him why her/his } \\
\text { behavior was wrong. } \\
\text { - I tell the child what behaviors are the right behaviors. } \\
\text { - I tell her/his how she/he might feel when these behaviors are } \\
\text { made to herself/himself. } \\
\text { - Even though we're right, I'm telling child that such as behavior } \\
\text { hitting, pushing, spitting, getting a toy from hands of children, etc. } \\
\text { are not the right behaviors. }\end{array}$ & $9-21 \%$ \\
\hline & Problem Solving & $\begin{array}{l}\text { - I take precautions to prevent aggressive behavior in children. I } \\
\text { make an individual conversationan focusing on problem solving } \\
\text { with chils' mother, } \\
\text { - I make an individual conversation with the family to solve the } \\
\text { problem. }\end{array}$ & $3-7 \%$ \\
\hline & Information Seeking & - I'il ask the child why hit friends. & $4-\% 10$ \\
\hline
\end{tabular}




\begin{tabular}{|c|c|c|c|}
\hline & & $\begin{array}{l}\text { - Slowly approaching their sides, watching the children's behavior } \\
\text { and trying to find the source of the problem. }\end{array}$ & \\
\hline & General & $\begin{array}{l}\text { - I'm telling the children that such as behavior of pushing their } \\
\text { friends, shooting, biting, throwing them toys is not right behavior. } \\
\text { - I'm talking about the pushing and shooting behavior is not } \\
\text { appropriate behavior after the child has calmed down. }\end{array}$ & $3-7 \%$ \\
\hline \multirow[t]{3}{*}{ Encouragement } & Facilitating Play & $\begin{array}{l}\text {-I help them to understand that physical aggression is not the right } \\
\text { behaviour and I encourage positive relationships with drama } \\
\text { method. } \\
\text { - I'm watched videos to children about the importance of playing } \\
\text { together without damaging your friends. } \\
\text { - I explain the importance of friendship with puppetry. }\end{array}$ & $5-12 \%$ \\
\hline & $\begin{array}{l}\text { Direct Involvement } \\
\text { in Children's Play }\end{array}$ & $\begin{array}{l}\text { - I organize events and participate in activities where they can } \\
\text { exhibit positive behaviors. }\end{array}$ & $3-7 \%$ \\
\hline & $\begin{array}{l}\text { Engaging in } \\
\text { Positive Play } \\
\text { with Peers }\end{array}$ & -I'm helping them understand the beauty of playing together. & $4-\% 10$ \\
\hline \multirow{4}{*}{ Power Assertion } & Punishment & $\begin{array}{l}\text { - I deprives to children from awarding inside the classroom. } \\
\text { - I'm punishing her/him by removing his favorite toy when I need } \\
\text { it. } \\
\text { - I deprive the child of attending the event her/his loves, going on a } \\
\text { trip, taking him to the garden. } \\
\text { - I'm applying a punishment to child's persistent aggressive } \\
\text { behavior. } \\
\text { - I take the class to a corner, give the child time out and ask her/him } \\
\text { to think about her/his behavior. } \\
\text { - I'm sending the child to the break corner and I'm punishing } \\
\text { her/him not to participate in the activity. }\end{array}$ & $14-33 \%$ \\
\hline & Prohibitions & $\begin{array}{l}\text { - I'm giving immediately feedback to the problem behaviors and } \\
\text { prevent the problem behavior. } \\
\text { - I forbid negative physical behavior in the class and try to right } \\
\text { this behavior. } \\
\text { - In the first two months, I constantly remind the class and school } \\
\text { rules clearly. } \\
\text { - I'm using the behavior panel, I am deprived of awards in the days } \\
\text { of children showing physical aggression. } \\
\text { - I reinforce classroom rules with pictures. }\end{array}$ & $12-29 \%$ \\
\hline & $\begin{array}{l}\text { Removal/ } \\
\text { Distraction }\end{array}$ & - I'm directing two child in a different direction. & $1-2 \%$ \\
\hline & Reprimand & $\begin{array}{l}\text {-I warn the aggressive child and I warn again and again. } \\
\text { - I warn the aggressive } \\
\text { - I'd tell the child that her/his aggressive behavior is unacceptable. }\end{array}$ & $3-7 \%$ \\
\hline
\end{tabular}




\begin{tabular}{|c|c|c|c|}
\hline & Reparations & $\begin{array}{l}\text {-I want an aggressive child to apologize to her/his friend. } \\
\text { - I say this is not right of children's behavior, I want to apologize } \\
\text { on friends. } \\
\text { - I take the toy from the hands of the child who shows physical } \\
\text { aggression and give it to her/his friend. }\end{array}$ & $3-7 \%$ \\
\hline \multirow{3}{*}{ Rule violation } & Reassurance & $\begin{array}{l}\text { - I'm trying to calm down and comfort the child who has suffered } \\
\text { from physical aggression. }\end{array}$ & $3-7 \%$ \\
\hline & $\begin{array}{l}\text { Target Victim rather } \\
\text { than Aggressor }\end{array}$ & $\begin{array}{l}\text { - Child who has suffered physical aggression, I'm helping her/him } \\
\text { make other compatible friends. } \\
\text { - I give verbal reinforcements to children who do not exhibit } \\
\text { physical behavior in the classroom. } \\
\text {-I give prizes to children who do not exhibit physical behaviors in } \\
\text { the classroom so that they can be a model for other children. }\end{array}$ & $16-38 \%$ \\
\hline & $\begin{array}{l}\text { Distract from } \\
\text { Problem }\end{array}$ & $\begin{array}{l}\text { - I prevent the child's aggressive behavior and reward their positive } \\
\text { behavior. } \\
\text { - When the children exhibit the right Behavior, I give the them } \\
\text { awards. }\end{array}$ & $12-29 \%$ \\
\hline
\end{tabular}

Review of Table 10 demonstrated that teachers generally use the methods of discussion and encouragement as solution-based intervention strategies to prevent physical aggression. Teachers stated that they generally use the methods of power assertion and rule violation non solution-based intervention strategies to prevent physical aggression.

\section{Discussion}

In this section, "Is there a significant relationship between children's social behavior, relational aggression and teachers' intervention strategies for relational aggression?" and "Is there a significant relationship between children's social behavior, physical aggression and teachers' intervention strategies for physical aggression?" questions of the research are discussed. In the research, it was found that there was a moderate positive correlation between children's social behaviors scores and teachers' scores of using discussion and encouragement intervention strategies in relational and physical aggression. Moreover, a moderate negative correlation was found between children's social behaviors scores and teachers' scores of using power assertion and rule violation intervention strategies in relational and physical aggression. In the research, a negative high-level relationship was found between children's relational and physical aggression scores and teachers' scores of using discussion and encouragement intervention strategies in relational aggression, and a moderate significant relationship was discovered between children's relational and physical aggression scores and teachers' scores of using power assertion and rule violation intervention strategies. Teachers' use of non-functional strategies in children's physical relational aggression does not prevent and reduce children's physical-relational aggression. Teachers' use of functional strategies in physical-relational aggression of children is related to the increase of children's social behaviors. The coercive behaviors of parents and teachers in 
the micro-system and mesosystem of Bronfenbrenner's ecological system theory to intervene in the child's aggression provides experiences that cause children to strengthen aggression over time (Lansford, 2018). Peets and Kikas (2017) found that child-centered practices were useful in the classes with high victimization and prevented in-class aggressive behaviors. They found that teachercentered practices increased aggressive behaviors in children.

In this section, "Do the child's relational aggression levels differ according to the intervention strategies of the teachers regarding relational aggression?" and "Do the child's physical aggression levels differ according to the intervention strategies of the teachers regarding physical aggression?" questions of the research are discussed. In the study, it was seen that the relational and physical aggression scores of the children differ significantly according to the discussion, encouragement, power assertion and rule violation strategies used by teachers to intervene in relational aggression. The relational and physical aggression scores of the children in the classroom of teachers highly using discussion and encouragement strategies in intervening relational and physical aggression were lower than the relational aggression scores of the children in the classroom of the teachers who use these strategies at medium and low level. The relational and physical-aggression scores of the children in the classroom of teachers highly using power assertion and rule violation strategies in intervening relational and physical aggression were higher than the relational and physical-aggression scores of the children in the classroom of the teachers who use these strategies at medium and low level. According to the results of this study, it can be said that intervention strategies used by teachers to prevent relational and physical aggression of children are important in terms of relational and physical aggression of children. Relational aggression involves behaviors, such as mocking, forcing to remain silent, spreading gossip, and intending to damage the child's social status. In addition, relational aggression is a form of deliberate and hidden bullying that aims to harm others through social exclusion, humiliation and personal rejection. Relational aggression, also known as indirect aggression, is a passive, aggressive, manipulative way of harming others (Moretti et al., 2005). Relational aggression has devastating effects on both the aggressive child and the targeted child. With the development of verbal and social cognitive skills, children begin to use relational aggression at the age of four-five. Children who discover that they can get their peers to do what they want by using relational aggression strategies at this age, will be master on using these strategies as they get older. Teachers' use of strategies that allow open communication through their words and actions to intervene in children's relational aggression makes it easier for children to cope with these negative behaviors (Redden, 2013; Crick et al, 2006; Ostrov et al., 2004). Especially teachers' focus on emotions in fighting against relational aggression, explaining why these behaviors are not correct, problem-based approach and efforts to find the causes of aggressive behaviors reduce negative behaviors. Negative strategies used by teachers to tackle relational aggression in early childhood were turned into the strategies of relational aggression developed by the children (Juliano et al., 2006). For this reason, it was found that more relational aggression is observed among the children of the teachers who use authority-based and victim-directed interventions more than discussion and support strategies. Hinshaw and Anderson (1996) found that compelling, prohibitive, and victim targeted solutions used to intervene in the aggressive behavior of the children increased their aggressive behavior. However, they found 
that the use of effective deterrence interventions (explaining, empathizing, social problem solving, etc.) improved children's social behavior. Patterson and Capaldi (1991) found that children in the classroom of adults exercising authority-based discipline exhibited more aggressive behavior. Teachers' attitudes and reactions against children's physical aggression were more negative than their attitudes and reactions against their relational aggression. Children's physical aggression behaviors were seen as unacceptable by their teachers. This fact directly affects the strategies that teachers have developed to fight against physical aggression. Teachers mostly prefer to use authority-based and victim-oriented strategies to prevent physical aggression in children. However, the authority-based use of power assertion (such as punishment, prohibition of behavior, forcing to apology, suspension, giving the toy to the victim, etc.) used by teachers to prevent and reduce physical aggression of children, and solutions targeting the victim (helping the victim to make new friends, calming the victim, removing the victim from the problem, etc.) increase physical aggression instead of reducing it (Crick \& Grotpeter, 2005). The teacher, who attempts to suppress the child's physical aggression behavior by using these strategies, indirectly shows to the children that these strategies are useful to achieve what they want (Colwell et al., 2002; Risser, 2004; Stockdale et al., 2002). In addition, solutions targeting the victim ensure that the demands of the child who exhibits physical aggression are met. Hence, the child continues to make other children do what he/she wants by using force and even increases his/her negative behaviors (Dellasaga \& Nixon, 2003; Simmons, 2003).On the other hand, teachers' use of discussion and encouragement strategies to intervene in physical aggression reduces children's negative behaviors by increasing open communication and interaction with children. Webster-Straton and Reid (2019) found that teachers' being a role-model for appropriate social interaction, emotion regulation and expressing emotions in appropriate ways abilities reduce children's aggressive behaviors.

In this section, "Do the child's social behavior levels differ according to the intervention strategies of the teachers regarding relational aggression?" and "Do the child's physical social behavior differ according to the intervention strategies of the teachers regarding physical aggression?" questions of the research are discussed. In the study, it was seen that the social behavior scores of the children differed significantly according to teachers' level of using discussion, encouragement, power assertion and rule violation strategies to intervene in relational and physical aggression. As teachers' levels of using discussion and encouragement strategies to intervene in relational and physical aggression increase, the social behavior scores of the children increase as well. The social behavior scores of the children in the classroom of teachers highly using power assertion and rule violation strategies in intervening relational aggression were lower than the behavior scores of the children in the classroom of the teachers who use these strategies at medium and low level. Social behaviors of children can be acquired through social life. Social behaviors are acquired through social learning, role-modeling and reinforcement. Therefore, in order to acquire a behavior, children need an environment in which they can exhibit social behaviors, an appropriate learning experience, a model that exhibits the behavior, and reinforcers that increase the repetition of behavior. In early childhood, the demands of each child to fulfill their wishes cause conflicts. Children's conflicts with their peers allow them to understand that they have different perspectives and 
that others also have rights and desires. However, in this period the strategies that children develop to resolve these conflicts are more important than the conflicts they have with their peers. The basis of children's relational and physical aggression may be children's lack of knowledge about alternative strategies that lead to positive results, and that can be used instead of aggressive strategies in conflict resolution. Since the discussion and support strategies that teachers use in intervening physical and relational aggression provide positive alternative solutions for resolving conflicts with children 's peers, they make contributions to children's acquisition of this social behavior (Feldman, 2009;). Therefore, the teacher's level of using negatively and positively oriented strategies to intervene in children's relational and physical aggression increases or decreases the social behavior levels of the children.

In this section, "What are the opinions of teachers about the strategies they use in interventions regarding children's physical and relational aggression?" questions of the research are discussed. In the qualitative dimension of the study, the methods used by preschool teachers in the strategies to cope with physical relational aggression were examined. Teachers use powerful assertion and rule violation strategies to intervene in children's physical aggression rather than intervening in relational aggression. Physical aggression behaviors are less approved by the society, whereas relational aggression behaviors are more approved. Therefore, physical aggression behaviors of children are mostly attempted to be suppressed by power assertion and rule violation by adults. Coplan et al. (2015) stated that pre-school teachers have more negative attitudes and beliefs towards children's physical aggression. However, it was found that preschool teachers use punishment, prohibition and reparations intervention strategies more than discussion and encouragement intervention strategies in the intervention of children's physical and relational aggression. It can be said that preschool teachers use non-functional strategies to intervene in physical and relational aggression of children. The reason why teachers often use authority-based and non-functional strategies addressing the victims of relational and physical aggression may be their lack of knowledge about alternative functional strategies or how to use these strategies. Webster-Stratton and Reid (2009) found that teachers' strategies in the intervention of these behaviors in children were important in reducing the physical and relational aggression of children. They found that speaking, listening, problem solving, joining the game, explaining the rules of empathy and supporting/encouraging strategies of the teachers to intervene in the problem behaviors and aggression behaviors reduce these negative behaviors of the children. Juliano et al. (2006) found that mothers use power assertion and rule violation strategies more in their children's physical aggression than relational aggression. They also found that mothers were insufficient to provide functional solutions to physical and relational aggression of children.

\section{Conclusion}

Preschool teachers may be trained on appropriate strategies to intervene in physical aggression and relational aggression, and the results can be analyzed. Studies may be conducted to determine which kind of physical aggression and relational aggression intervention strategies are used by preschool teachers. Res factor in physical aggression and relational aggression of the children and the results may be evaluated. Each may be 
conducted to determine the physical and relational aggression observed in children by preschool teachers. This research may be conducted in parents who may be an important factor in physical aggression and relational aggression of the children and the results may be evaluated.

\section{References}

Ahmetoğlu, E. (2018). Social development. Early childhood education and development. İstanbul: Pandora Publishing.

Archer, J., \& Coyne, S. M. (2005). An integrated review of indirect, relational, and social aggression. Personality and Social Psychology Review, 9(3), 212-230. https://doi.org/ 10.1207/s15327957pspr0903_2

Bartol, C. R. (1995). Criminal Behavior: A Psychological Approach. Englewood Cliffs, NJ: Prentice Hall.

Blair, K. A., Denham, S. A., Kochanoff, A., \& Whipple, B. (2004). Playing it cool: Temperament, emotion regulation, and social behavior in preschoolers. Journal of School Psychology, 42, 419-443. https://doi.org/10.1016/j.jsp.2004.10.002

Brendgen, M., Vitaro, F., Boivin, M., Dionne, G., \& Pérusse, D. (2006). Examining genetic and environmental effects on reactive versus proactive aggression. Developmental Psychology, 42(6), 1299-1312. https://doi.org/10.1037/0012-1649.42.6.1299

Büyüköztürk, Ş., Kılıç Çakmak, E., Akgün, Ö. E., Karadeniz, Ş., \& Demirel, F. (2008). Scientific research methods. Ankara: Pegem Publishing.

Colwell, M. J., Mize, J., Pettit, G. S., \& Laird, R. D. (2002). Contextual determinants of mothers' interventions in young children's peer interactions. Developmental Psychology, 38, 492-502. https://doi.org/10.1037/0012-1649.38.4.492

Coplan, R. J., Bullock, A., Kristen, A. A., \& Bosacki, S. (2015). Preschool teachers' attitudes, beliefs, and emotional reactions to young children's peer group behaviors. Early Childhood Research Quarterly, 30, 117-127. https://doi.org/10.1016/j.ecresq.2014.09.005

Crapanzano, A. M., Frick, P. J., \& Terranova, A. M. (2010). Patterns of physical and relational aggression in a school-based sample of boys and girls. Journal of Abnormal Child Psychology, 38(4), 433-445. https://doi.org/10.1007/s10802-009-9376-3

Crick, N. R., \& Grotpeter, J. K. (2005). Relational aggression, gender, and social-psychological adjustment. Child Development, 66(3), 710-722. https://doi.org/10.2307/ 1131945

Crick, N. R., Casas, J. F., \& Mosher, M. (1997). Relational and overt aggression in preschool. Developmental Psychology, 33(4), 579-588. https://doi.org/10.1037/0012-1649.33.4.579

Crick, N. R., Ostrov, J. M., Burr, J. E., Cullerton-Sen, C., Jansen-Yeh, E., \& Ralston, P. (2006). A longitudinal study of relational and physical aggression in preschool. Applied Developmental Psychology, 27, 254-268. https://doi.org/10.1016/j.appdev.2006.02.006 
Del'homme, M. A., Sinclair, E., \& Kasari, C. (1994). Prechool children with behavioral problems: Observation in instructional and free play contexts. Behavioral Disorders, 19(3), 221-232. https://doi.org/10.1177/019874299401900301

Dellasega, C., \& Nixon, C. (2003). Girl Wars-12 strategies that will end female bullying. Sydney: Simon \& Schuster Publishing.

Elliott, S. N., \& Treuting, M. V. (1991). The behavior intervention rating scale: Development and validation of a pretreatment acceptability and effectiveness measure. Journal of School Psychology, 29(1), 43-51. https://doi.org/10.1016/0022-4405(91)90014-I

Feldman, S. R. (2009). Development across the life span. Boston: Pearson.

Fraenkel, J. R., \& Wallen, N. E. (2006). How to design and evaluate in education. New York: McGraw-Hill.

Gornik, A. E., Neal, J. W., Sharon, L. L., \& Durbin, C. E. (2018). Connections between preschoolers' temperament traits and social behaviors as observed in a preschool setting. Social Development, 27, 335-350. https://doi.org/10.1111/sode.12271

Hinshaw, S. P., \& Anderson, C. A. (1996). Conduct and oppositional defiant disorders. In E. J. Mash \& R. A. Barkley (Eds.), Child psychopathology (pp. 113-149). New York: Guilford Press.

Hollingsworth, H. L., \& Winter, M. K. (2013). Teacher beliefs and practices relating to development in preschool: importance placed on social-emotional behaviours and skills. Early Child Development and Care, 183(12), 1758-1781. https://doi.org/10.1080/03004430. 2012.759567

Juliano, M., Werner, R. S., \& Cassidy, K.W. (2006). Early correlates of preschool aggressive behavior according to type of aggression and measurement. Journal of Applied Developmental Psychology, 27, 395-410. https://doi.org/10.1016/j.appdev.2006.06.008

Kamper-DeMarco, K. E., \& Ostrov, J. M. (2019). The Influence of Friendships on Aggressive Behavior in Early Childhood: Examining the Interdependence of Aggression. Child Psychiatry \& Human Development, 50, 520-531. https://doi.org/10.1007/s10578-018-0857-x

Karasar, N. (2018). Scientific research method. Ankara: Nobel Academic Publishing

Lansford, J. E. (2018). Development of aggression. Current Opinion in Psychology, 19, 17-21. https://doi.org/10.1016/j.copsyc.2017.03.015

Lara-Cinisomo, S., Fuligni, A. S., Daugherty, L., Howes, C., \& Karoly, L. (2009). A qualitative study of early childhood educators' beliefs about key preschool classroom experiences. Early Childhood Research \& Practice, 111(1), 1-17. https://doi.org/10.2139/ ssrn. 1333307

Lee, J. S. (2006). Preschool teachers' shared beliefs about appropriate pedagogy for 4-year-olds. Early Childhood Education Journal, 33(6), 433-441. https://doi.org/10.1007/ s10643-006-0059-1 
Lim, S. J., \& Hoot, J. L. (2015). Bullying in an increasingly diverse school population: A Social ecological model analysis. School Psychology International, 36(3), 268-282. https://doi.org/10.1177/0143034315571158

Miles, M, B., \& Huberman, A. M. (1994). Qualitative data analysis: An expanded Sourcebook. CA: Sage Publishing.

Mize, J., Pettit, G. S., \& Brown, E. G. (1995). Mothers' supervision of their children's peer play: Relations with beliefs, perceptions, and knowledge. Developmental Psychology, 31(2), 311-321. https://doi.org/10.1037/0012-1649.31.2.311

Moretti, M., Catchpole, E., \& Odgers, C. (2005). The dark side of girlhood: Recent trends, risk factors and trajectories to aggression and violence. Canadian Academy of Child and Adolescent Psychiatry, 14(1), 21-25.

Ostrov, J. M., \& Keating, C. F. (2004). Gender differences in preschool aggression during free play and structured interractions: An observational study. Social Development, 13(2), 255-277. https://doi.org/10.1111/j.1467-9507.2004.000266.x

Ostrov, J. M., Woods, K. E., Jansen, E. A., Casas, J. F., \& Crick, N. R. (2004). An observational study of delivered and received aggression, gender, and social-psychological adjustment in preschool: "This white crayon doesn't work...". Early Childhood Research Quarterly, 19, 355-371. https://doi.org/10.1016/j.ecresq.2004.04.009

Patterson, G. R., \& Capaldi, D. M. (1991). Advances in family research series. Family transitions. US: Lawrence Erlbaum Associates.

Peets, K., \& Kikas, E. (2015). Teachers' promotion or inhibition of children's aggression depends on peer-group characteristics. Journal of Clinical Child \& Adolescent Psychology, 46(6), 848-857. https://doi.org/10.1080/15374416.2015.1079778

Redden, C. V. (2013). The Media's influence on female relational aggression and its Implications for Schools. Canadian Journal of Education, 36(4), 374-393

Risser, S. (2004). Student and mother perceptions of physical and social aggression. Poster presented at the biennial meetings of the Society for Research on Child Development. Tampa, FL.

Şen, M., \& Arı, M. (2011). Reliability and validity study of the preschool social behavior scale-teacher form. Ankara University, Journal of Faculty of Educational Sciences, 44(2), 1-28. https://doi.org/10.1501/Egifak_0000001222

Simmons, R. (2002). Odd girl out: The hidden culture of aggression in girls. New York: Harcourt.

Stockdale, M. S., Haungaduambo, S., Duys, D., Larson, K., \& Sarvela, P. D. (2002). Rural elementary students', parents', and teachers' perceptions of bullying. American Journal of Health Behavior, 26, 266-277. https://doi.org/10.5993/ajhb.26.4.3

Webster-Stratton, C. (2009). Affirming diversity: Multi-cultural collaboration to deliver the 


\section{Macrothink}

incredible years parent programs. International Journal of Child Health and Human Development, 2(1), 17-32.

Webster-Stratton, C., \& Reid, M. J. (2009). Parents, teachers and therapists using the child-directed play therapy and coaching skills to promote children's social and emotional competence and to build positive relationships. In C. E. Schaefer (Ed.), Play therapy for preschool children (pp. 245-273). Washington, DC: American Psychological Association. https://doi.org/10.1037/12060-012

\section{Copyright Disclaimer}

Copyright for this article is retained by the author(s), with first publication rights granted to the journal.

This is an open-access article distributed under the terms and conditions of the Creative Commons Attribution license (http://creativecommons.org/licenses/by/3.0/). 